China Perspectives

46 | march-april 2003

Varia

\title{
Frank Dikötter, Crime, Punishment and the Prison in Modern China
}

Hong Kong University Press, 2002, 441 pp.

Leïla Choukroune

\section{OpenEdition}

\section{Journals}

Édition électronique

URL : http://journals.openedition.org/chinaperspectives/266

DOI : $10.4000 /$ chinaperspectives. 266

ISSN : 1996-4617

\section{Éditeur}

Centre d'étude français sur la Chine contemporaine

Édition imprimée

Date de publication : 15 avril 2003

ISSN : 2070-3449

\section{Référence électronique}

Leilla Choukroune, «Frank Dikötter, Crime, Punishment and the Prison in Modern China », China

Perspectives [En ligne], 46 I march-april 2003, mis en ligne le 29 août 2006, consulté le 24 septembre 2020. URL : http://journals.openedition.org/chinaperspectives/266 ; DOI : https://doi.org/10.4000/ chinaperspectives.266

Ce document a été généré automatiquement le 24 septembre 2020

(c) All rights reserved 


\title{
Frank Dikötter, Crime, Punishment and the Prison in Modern China
}

Hong Kong University Press, 2002, 441 pp.

\author{
Leïla Choukroune
}

\section{NOTE DE L'ÉDITEUR}

Translated from the French original by Peter Brown

1 Every reader of Discipline and Punish has indelibly engraved in their mind the description of Damiens' terrible ordeal at the start of Michel Foucault's work. Damiens had been sentenced in Paris on March 2nd 1757. Only a few years separated his public execution from the drawing up of a projected modern penal code that was completed in 1791. A handful of decades were enough to have the martyred body and its mise en scène disappear in favour of a "humanisation" of punishment. This meant that the body was no longer the prime object of sentencing, but rather became the channel through which the imprisoned individual was deprived of his freedom. Punishment thus went from being "an art of unbearable sensations" to an "economy of suspended rights" 1 .

2 A century later, in China, access to the humanity of punishment was also marked by the widespread introduction of the prison system. Whereas imperial China did not regard the time an accused person spent in its jails, while awaiting trial, as being part of the sanction, the post-1905 China gradually came to make prisons the focal point of its system of repression.

3 This is a work of remarkable scholarship, based on a no less impressive analysis of sources as little known as the municipal archives in Peking or the provincial archives in Liaoning province on the penal administration of the early years of Republican China. In it, Frank Dikötter takes us, between 1895 and 1949, to the deepest recesses of a world of incarceration founded on a modern understanding of the philosophy of punishment. The writer states that this new view of crime and its punishment was part of a constant striving to educate the Chinese people in terms of the imperative of virtue. The idea 
according to which even the most hardened criminal was capable of repentance and self-rehabilitation through a process of moral transformation (ganhua) is thus placed at the heart of the penal philosophy of modern China: "The prison, in other words, was part of a new mode of governance in which political legitimacy was vested in the nation"'.

Crime, Punishment and the Prison in Modern China is divided into three main parts. Part I presents the emergence of a modern penal system. Part II concerns the various conceptions of the science of crime and its sanctioning. Part III deals with prisons under the Kuomintang. The first part gives an account, from a new angle, of a process of Westernisation and modernisation of Chinese law that is relatively well known to legal scholars. The section dealing with the influence of Shen Jiaben (1840-1913) in the construction of a modern penal system is revealing in this regard. Appointed by the Qing in 1904 as one of those responsible for the office of Codification (Falüguan), he strived to propagate the idea of a "light" (xingqing) sanctioning of crimes by condemning the traditional punishment inflicted on prisoners, like dismemberment or decapitation followed by the displaying of the victim's head in public. These practices were abolished between 1904 and 1910, while corporal punishment using bamboo was replaced by fines ${ }^{3}$. For Shen Jiaben, prison reform provided a useful gauge of the degree of civilisation or barbarism of a society. Peking's model prison was not the only one to apply this new kind of method. Indeed, Frank Dikötter shows very clearly that, by 1927, most of the coastal provinces and those of China's northeast could boast of having two to three prisons of this type. Conversely, the far-flung provinces of Qinghai or Xinjiang built their first modern detention centres during the Second World War, while the central government was seeking refuge in Chongqing to escape the Japanese. The second, more theoretical, part is concerned with demonstrating that the emergence of a new penal system in China rested on a radically new conception of crime and its punishment. Thus, the writer analyses the development of "the science of prisons" (jianyuxue), and that of criminology (fanzuixue). While the doctrines of Sun Xiong or Rui Jiarui promoted the educational and moral virtues of prison (jiaohua), Li Jianhua adopted a Marxist and utopian vision of what the philosophy of punishment should have been in a world still dominated by capitalism by taking the Soviet model as an example ${ }^{4}$. The only alternative to a modernising Westernisation was therefore to come from the Soviet Empire and its system of communes, even after it had purged millions of people between 1934 and 1939. The third and final part offers a detailed overview of prisons under the Kuomintang, both nationally and locally, through the example of Shanghai.

We should also observe that this work provides us with original and highly interesting iconographical material, for instance, in the different snapshots of daily life in Peking's model prison (washroom, kitchens, sports yards, craft workshops, exhibition hall used for displaying their products, etc.). One of these snapshots surprisingly shows the portraits of five important figures: Jesus Christ, Laozi, Confucius, John Howard and Mohammed! Indeed, the section that Frank Dikötter devotes to the No. 1 prison in Peking very clearly brings out the fact that one of the missions of these modern detention centres was to educate the prisoners, and, in relation to the idea of ganhua, to provide them with religious instruction useful for their moral development (see pp. 69 to 93). The critical apparatus is also very well developed, the reader being able, in particular, to find references to the various archival documents consulted by the 
author. Finally, a ten-page glossary lists the Chinese names and expressions that recur frequently throughout the work.

7 The only minor fault is perhaps that the author has not adequately set out his conclusions. As paradoxical as it may seem, we are left still wanting a little more after reading these 500 pages, as if too many details contributed to drowning out the general thesis. Although that is the logical consequence of the historical format chosen by the writer, it is also rather frustrating not to be able to understand what really changed in the penitentiary system after 1949, particularly given that Frank Dikötter seems to think that "the entire republican period may one day be seen as a fascinating laboratory of modernity which brought about profound cultural, social and political changes, many of which were swept away after 1949 " ${ }^{5}$. If we are to believe reports that we regularly hear about the conditions of detention and the nearly systematic use of torture there, the Chinese prisons of the twenty-first century certainly do not participate in the humanisation of punishment advocated by the Enlightenment. Quite the contrary, analyses like those developed by Robin Munro ${ }^{6}$ lead us to believe that the conclusions of any possible inspection team-we are thinking for example of the International Committee of the Red Cross-would doubtless not be as measured as those of the Committee that, in 1926, was given the responsibility of examining Chinese prisons and, more generally, the whole judicial system ${ }^{7}$.

\section{NOTES}

1. Michel Foucault, Discipline and Punish. The Birth of the Prison, London, Allen Lane, Penguin Books, 1975 (translated by Alan Sheridan), p. 11 Surveiller et punir, naissance de la prison, Paris, Gallimard, 1977, p. 18.

2. Frank Dikötter, Crime, Punishment and the Prison in Modern China, p. 8.

3. We should, however, note that this practice was reintroduced in Peking's No. 1 prison in 1914. See "Punishment inside the Prison", p. 101 and following.

4. Respectively Director of the No. 2 prison in Shanghai and the No. 4 prison in Jiangsu province, then Professor at Fudan University; Researcher with the research centre on prison administration and author of a handbook on penal administration; and Professor specialising in labour law at Fudan.

5. See p. 371.

6. "Judicial Psychiatry in China and its Political Abuses”, Columbia Journal of Asian Law, Vol. 14, No. 1, Spring 2000, pp. 1-125.

7. See the conclusions of the first part, pp. 138-140. 